\title{
Effect of Soil Conditioner and INM on Yield of Mungbean (Co: 4) Grown on Partially Reclaimed Coastal Salt Affected Soil of South Gujarat, India
}

\author{
S.D. Chaudhari, V.R. Naik, J.M. Patel and H.B. Sodavadiya* \\ Department of Agronomy, N. M. College of Agriculture, Navsari Agricultural University, \\ Navsari-396 450. Gujarat, India \\ *Corresponding author
}

\section{A B S T R A C T}

A field experiment was conducted at Coastal Soil Salinity Research Station, Navsari Agricultural University, Danti-Umbharat during rabi season of the year 2015-16 on "Effect of soil conditioner and INM on yield of mungbean (var Co: 4) grown on partially reclaimed coastal salt affected soil of South Gujarat". In all 10 treatment combinations consisting of two levels of soil conditioner $\left(\mathrm{G}_{1}=\right.$ Control, $\mathrm{G}_{2}=$ Gypsum application @ $2 \mathrm{t}$

Keywords

Mungbean, Soil conditioner, INM, Yield, Economics.

Article Info

Accepted:

23 June 2017

Available Online:

10 August 2017 $\left.\mathrm{ha}^{-1}\right)$, and five levels of INM (Integrated Nutrient Management) ( $\mathrm{F}_{1}:$ 100\% RDF(20:40:00 NPK kg ha ${ }^{-1}$ ), $\mathrm{F}_{2}: 100 \% \mathrm{RDF}+$ Bio-compost @ $5 \mathrm{t} \mathrm{ha}^{-1}+$ bio fertilizer (Rhizobium + $\mathrm{PSB}), \mathrm{F}_{3}: 75 \% \mathrm{RDF}+$ Bio-compost @ $5 \mathrm{t} \mathrm{ha}^{-1}+$ bio fertilizer (Rhizobium + PSB), $\mathrm{F}_{4}: 50 \%$ RDF+ Bio-compost @ $5 \mathrm{t} \mathrm{ha}^{-1}+$ bio fertilizer (Rhizobium + PSB) and $\mathrm{F}_{5}$ : Bio-compost @ $5 \mathrm{t} \mathrm{ha}^{-1}$ ) were tried in FRBD (Factorial Randomized Block Design) with four replications. The results revealed that soil conditioner and INM significantly influenced the yield and yield attributes of mungbean. Application of gypsum @ $2 \mathrm{t} \mathrm{ha}^{-1}$ was found significantly superior over control $\left(\mathrm{G}_{1}\right.$ : No gypsum) by recording higher values of number of pods per plant (33.1), number of seeds per pod (10.15), seed yield $\left(1130 \mathrm{~kg} \mathrm{ha}^{-1}\right)$ and stover yield $\left(3829 \mathrm{~kg} \mathrm{ha}^{-1}\right)$ as compared to rest of the INM levels. The $\mathrm{G} \times \mathrm{F}$ interaction was also found to be significant for all the above characters. In all the cases, treatment $\mathrm{G}_{2} \mathrm{~F}_{2}$ recorded $34.90,10.62,4065 \mathrm{~kg} \mathrm{ha}^{-1}$ and $1185 \mathrm{~kg} \mathrm{ha}^{-1}$ values of number of pods per plant, number of seeds per pod, stover yield and seed yield, respectively, which were significantly superior over rest of the treatments. However $\mathrm{G}_{2} \mathrm{~F}_{2}$ in most of the cases remained at par with treatment $\mathrm{G}_{2} \mathrm{~F}_{3}$. The net return as well as a $\mathrm{BCR}$ value was also higher with the treatment $\mathrm{G}_{2} \mathrm{~F}_{\text {? }}$

\section{Introduction}

Mungbean (Vignaradiata L. Wilczek) occupies prime position among pulses by virtue of its short growth period and outstanding nutrient value as food, feed and forage. The average yield of mungbean in India is very low because it is generally cultivated on marginal land with poor management practices. There is always short supply of pulses in our country as a result of which there is wide spread prevalence of protein malnutrition in Indian population. In order to resolve this problem, it is rather imperative to increase production of pulses through either enhancing productivity or area expansion by bringing partially reclaimed/marginally salt affected coastal land under pulses cultivation. However, for achieving economically viable yield level of pulses under such situations, special soil and nutrient management practices are required to 
be adopted. As the information related to these aspects is lacking, a study on the effect of gypsum and INM on growth and yield of mungbean grown on partially reclaimed coastal salt affected soils of South Gujarat was taken up and the results are presented here.

\section{Materials and Methods}

A field experiment was conducted at Coastal Soil Salinity Research Station, Navsari Agricultural University, Danti-Umbharat (Gujarat) during rabi season of the year 201516. The experimental soil is clayey in texture with low in organic carbon $(0.31 \mathrm{~g} / \mathrm{kg})$, available $\mathrm{N}\left(207 \mathrm{~kg} \mathrm{ha}^{-1}\right)$ and available $\mathrm{P}$ $\left(27.1 \mathrm{~kg} \mathrm{ha}^{-1}\right)$ but high in available $\mathrm{K}(2465 \mathrm{~kg}$ $\left.\mathrm{ha}^{-1}\right)$. In all 10 treatment combinations consisting of two levels of soil conditioner $\left(\mathrm{G}_{1}\right.$ : Control and $\mathrm{G}_{2}$ : Application of gypsum @ 2t $\left.\mathrm{ha}^{-1}\right)$ and five levels of INM $\left(\mathrm{F}_{1}: 100 \%\right.$ RDF (20:40:00 NPKkg ha $\left.{ }^{-1}\right), F_{2}: 100 \%$ RDF + Bio-compost @ 5 t ha ${ }^{-1}+$ bio fertilizer (Rhizobium + PSB), $\mathrm{F}_{3}=75 \% \mathrm{RDF}+$ Biocompost @ $5 \mathrm{t} \mathrm{ha}^{-1}+$ bio fertilizer (Rhizobium + PSB), $\mathrm{F}_{4}=50 \% \mathrm{RDF}+$ Bio-compost @ $5 \mathrm{t}$ $\mathrm{ha}^{-1}+$ bio fertilizer (Rhizobium + PSB) and $\mathrm{F}_{5}=$ Bio-compost @ $\mathrm{t} \mathrm{ha}^{-1}$ ) were tested in Factorial RBD with four replications. Treatment wise gypsum and biocompost were applied a week before sowing, while the chemical fertilizers were applied just before sowing in previously opened furrow. Mungbean cultivar Co: 4 was sown on $22^{\text {th }}$ November on raised bed at $30 \mathrm{~cm} \times 75 \mathrm{~cm}$ (paired row) spacing. Crop was fertilized as per treatments. Two hand weeding and one interculturing were carried out during the early crop growth stages. Observations related to growth characters viz., plant height, number of branches per plant at 20,40 and 60 DAS and yield attributes (number of pods per plant and seed per pods) at harvest stage were recorded from pretagged plants. Seed and stover yields from net plot area were recorded. The data obtained were statistically analyzed by the method suggested by Panse and Sukhatme (1967).

\section{Results and Discussion}

\section{Yield}

\section{Effect of soil conditioner}

The results given in table 1 revealed that yield attributes as well as seed and stover yields were significantly influenced by soil conditioner treatment. Application of gypsum @ $2 \mathrm{t} \mathrm{ha}^{-1}\left(\mathrm{G}_{2}\right)$ increased number of pods plant $^{-1}$ and number of seeds pod ${ }^{-1}$ by 6.52 and 6.38 per cent, respectively over control. The increase in different yield attributing characters might be due to improvement in the physical conditions of the soil along with more availability of sulphur through gypsum during vegetative and reproductive stages of the crop. Sulphur helps in chlorophyll formation, photosynthetic process, and activation of enzymes and grain formation. Similar beneficial effects of application of soil conditioner on the yield attributes of mungbean have also been reported by Jat and Rathore (1994) and Patilet al., (2011) in mungbean.

Further, the results revealed that treatment $\mathrm{G}_{2}$ (Gypsum application@2t ha ${ }^{-1}$ ) recorded significantly higher seed (1038 kg ha-1) and stover yields (3590 kg ha-1) as compared to control. The per cent increase in seed and stover yields due to gypsym application @ $2 \mathrm{t}$ $\mathrm{ha}^{-1}\left(\mathrm{G}_{2}\right)$ was to the extent of 11 and 15 , respectively, over control $\left(\mathrm{G}_{1}\right)$. Favorable effect of gypsum application on yield attributes of greengram had ultimately resulted into significantly higher seed and stover yields. The results are in conformity with those reported by Patel et al., (2010), Patil et al., (2011) and Bairwa et al., (2012) for mungbean crop. 


\section{Effect of INM}

The yield attributes viz., number of pods plant $^{-1}$, number of seeds pod-1, seed yield and stover yield (Table 1) were affected significantly due to INM treatments. Application of $100 \%$ RDF + Bio-compost @ $5 \mathrm{tha}^{-1}+$ bio fertilizer (Rhizobium + PSB) $\left(\mathrm{F}_{2}\right)$ remarkably increased the number of pods plant $^{-1}(33.1)$ and number of seeds pod $^{-1}$ (10.15) followed by treatment $F_{3}$ and $F_{1}$.

Significantly the lowest values of all the above mentioned yield attributes were registered under treatment $\mathrm{F}_{5}$ [Bio-compost @ $5 \mathrm{tha}^{-1}$. The percentage increase in number of pods plant ${ }^{-1}$ and number of seeds pod $^{-1}$ were to the tune of 10,20 and $1.4,12$ per cent, respectively, with treatment $\mathrm{F}_{2}$ as compared to treatment $F_{1}$ and $F_{5}$, This might be due to adequate supply of nutrient from inorganic fertilizers and organic manure applied together. These findings are in agreement with those reported by and Sushil Vitnor et $a l$. , (2015) for greengram crop.

Among the INM treatments, application of $100 \% \mathrm{RDF}+$ Bio-compost @ $5 \mathrm{t} \mathrm{ha}^{-1}+$ bio fertilizer (Rhizobium + PSB) $\left(\mathrm{F}_{2}\right)$ recorded significantly higher seed yield (1130 kg ha $\left.{ }^{-1}\right)$ and stover yield (3829 $\left.\mathrm{kg} \mathrm{ha}^{-1}\right)$ which remained at par with treatment $\mathrm{F}_{3}(75 \% \mathrm{RDF}$ + Bio-compost @ $5 \mathrm{t} \mathrm{ha}^{-1}+$ bio fertilizer (Rhizobium + PSB). Higher seed yield of mungbean obtained under combined application of fertilizer and organics along with biofertilizer seems to be due to improvement in soil conditions and nutrient availability. These findings related to mungbean crop are in close conformity with those earlier reported by Kundu et al., (2013), Gorade et al., (2014), Singh et al., (2015), Tyagi and Upadhyay (2015) and Sushil Vintor et al., (2015).

Table.1 Yield attributes and yield of mungbean as influenced by different treatments

\section{a. Number of pods per plant}

\begin{tabular}{|c|c|c|c|c|c|c|}
\hline \multirow{2}{*}{ Soil conditioner $(\mathbf{G})$} & \multicolumn{5}{|c|}{ INM (F) } & \multirow{2}{*}{$\operatorname{Mean}(\mathbf{G})$} \\
\hline & $F_{1}$ & $F_{2}$ & $\mathbf{F}_{3}$ & $\mathbf{F}_{4}$ & $\mathbf{F}_{5}$ & \\
\hline$\overline{G_{1}}$ & 27.90 & 31.30 & 30.10 & 27.90 & 28.40 & 29.1 \\
\hline $\mathbf{G}_{2}$ & 32.10 & 34.90 & 32.50 & 28.60 & 27.00 & 31.0 \\
\hline Mean (F) & 30.0 & 33.10 & 31.30 & 28.30 & 27.70 & \\
\hline \multicolumn{2}{|l|}{ Source } & \multicolumn{2}{|c|}{ S.Em \pm} & \multicolumn{2}{|c|}{ C.D. } & C.V (\%) \\
\hline \multicolumn{2}{|l|}{ G } & \multicolumn{2}{|c|}{0.43} & \multicolumn{2}{|c|}{1.24} & 6 \\
\hline \multicolumn{2}{|l|}{$\mathbf{F}$} & \multicolumn{2}{|c|}{0.67} & \multicolumn{2}{|c|}{1.95} & \\
\hline \multicolumn{2}{|l|}{$\mathbf{G} \times \mathbf{F}$} & \multicolumn{2}{|c|}{0.95} & \multicolumn{2}{|c|}{2.76} & \\
\hline
\end{tabular}

\section{b. Number of seeds per pod}

\begin{tabular}{|c|c|c|c|c|c|c|}
\hline \multirow{2}{*}{ Soil conditioner $(\mathbf{G})$} & \multicolumn{5}{|c|}{ INM (F) } & \multirow{2}{*}{$\operatorname{Mean}(\mathbf{G})$} \\
\hline & $\mathbf{F}_{1}$ & $\mathbf{F}_{2}$ & $\mathbf{F}_{3}$ & $\mathbf{F}_{4}$ & $\mathbf{F}_{5}$ & \\
\hline $\mathbf{G}_{1}$ & 9.36 & 9.65 & 10.25 & 8.49 & 9.23 & 9.40 \\
\hline $\mathbf{G}_{2}$ & 10.45 & 10.65 & 9.90 & 10.09 & 8.90 & 10.0 \\
\hline Mean (F) & 9.91 & 10.15 & 10.08 & 9.29 & 9.07 & \\
\hline \multicolumn{2}{|l|}{ Source } & \multicolumn{2}{|c|}{ S.Em \pm} & \multicolumn{2}{|c|}{ C.D. } & C.V (\%) \\
\hline \multicolumn{2}{|l|}{$\mathbf{G}$} & \multicolumn{2}{|c|}{0.12} & \multicolumn{2}{|c|}{0.34} & 5 \\
\hline \multicolumn{2}{|l|}{$\mathbf{F}$} & \multicolumn{2}{|c|}{0.18} & \multicolumn{2}{|c|}{0.53} & \\
\hline \multicolumn{2}{|l|}{$\mathbf{G} \times \mathbf{F}$} & \multicolumn{2}{|c|}{0.26} & \multicolumn{2}{|c|}{0.75} & \\
\hline
\end{tabular}




\section{c. Stover yield $\left(\mathrm{kg} \mathrm{ha}^{-1}\right)$}

\begin{tabular}{|c|c|c|c|c|c|c|}
\hline \multirow{2}{*}{ Soil conditioner $(\mathbf{G})$} & \multicolumn{5}{|c|}{ INM (F) } & \multirow{2}{*}{ Mean $(G)$} \\
\hline & $\mathbf{F}_{1}$ & $\mathbf{F}_{2}$ & $F_{3}$ & $\mathbf{F}_{4}$ & $\mathbf{F}_{5}$ & \\
\hline $\mathbf{G}_{1}$ & 2916 & 3593 & 3426 & 3287 & 2398 & 3124 \\
\hline $\mathbf{G}_{2}$ & 3120 & 4065 & 4037 & 3370 & 3357 & 3590 \\
\hline Mean (F) & 3018 & 3829 & 3732 & 3329 & 2878 & \\
\hline \multicolumn{2}{|l|}{ Source } & \multicolumn{2}{|c|}{ S.Em \pm} & \multicolumn{2}{|c|}{ C.D. } & C.V (\%) \\
\hline \multicolumn{2}{|l|}{$\mathbf{G}$} & \multicolumn{2}{|c|}{66} & \multicolumn{2}{|c|}{191} & 9 \\
\hline \multicolumn{2}{|l|}{$\mathbf{F}$} & \multicolumn{2}{|c|}{104} & \multicolumn{2}{|c|}{303} & \\
\hline \multicolumn{2}{|l|}{$\mathbf{G} \times \mathbf{F}$} & \multicolumn{2}{|c|}{147} & \multicolumn{2}{|c|}{428} & \\
\hline
\end{tabular}

\section{d. Seed yield $\left(\mathrm{kg} \mathrm{ha}^{-1}\right)$}

\begin{tabular}{|c|c|c|c|c|c|c|}
\hline \multirow{2}{*}{ Soil conditioner $(\mathbf{G})$} & \multicolumn{5}{|c|}{ INM (F) } & \multirow{2}{*}{$\operatorname{Mean}(\mathbf{G})$} \\
\hline & $\mathbf{F}_{1}$ & $\mathbf{F}_{2}$ & $\mathbf{F}_{3}$ & $\mathbf{F}_{4}$ & $\mathbf{F}_{5}$ & \\
\hline $\mathbf{G}_{1}$ & 949 & 1074 & 1019 & 972 & 676 & 938 \\
\hline $\mathbf{G}_{2}$ & 940 & 1185 & 1176 & 963 & 924 & 1038 \\
\hline Mean (F) & 945 & 1130 & 1097 & 968 & 800 & \\
\hline \multicolumn{2}{|l|}{ Source } & \multicolumn{2}{|c|}{ S.Em \pm} & \multicolumn{2}{|c|}{ C.D. } & C.V (\%) \\
\hline \multicolumn{2}{|l|}{$\mathbf{G}$} & \multicolumn{2}{|c|}{20} & \multicolumn{2}{|c|}{58} & 9 \\
\hline \multicolumn{2}{|l|}{$\mathbf{F}$} & \multicolumn{2}{|c|}{32} & \multicolumn{2}{|c|}{92} & \\
\hline \multicolumn{2}{|l|}{$\mathbf{G} \times \mathbf{F}$} & \multicolumn{2}{|c|}{45} & \multicolumn{2}{|c|}{130} & \\
\hline
\end{tabular}

Table.2 Economics of different treatment combinations of soil conditioner and INM

\begin{tabular}{|c|c|c|c|c|c|c|}
\hline \multirow[b]{2}{*}{ Treatment } & \multicolumn{2}{|c|}{ Yield $\left(\mathrm{kg} \mathrm{ha}^{-1}\right)$} & \multirow{2}{*}{$\begin{array}{c}\text { Cost of } \\
\text { cultivation } \\
\left(₹ h^{-1}\right)\end{array}$} & \multirow{2}{*}{$\begin{array}{l}\text { Gross } \\
\text { return } \\
\left.\left(\text { ₹ }^{-1}\right)^{-1}\right)\end{array}$} & \multirow{2}{*}{$\begin{array}{c}\text { Net } \\
\text { return } \\
\left(\text { ₹ } \mathbf{h a}^{-1}\right)\end{array}$} & \multirow[b]{2}{*}{ BCR } \\
\hline & Seed & Stover & & & & \\
\hline $\mathbf{G}_{1} \mathbf{F}_{1}$ & 949 & 2916 & 29473 & 68602 & 39129 & $2.3: 1$ \\
\hline $\mathbf{G}_{1} \mathbf{F}_{2}$ & 1074 & 3593 & 32624 & 78810 & 46186 & $2.4: 1$ \\
\hline $\mathbf{G}_{\mathbf{1}} \mathbf{F}_{\mathbf{3}}$ & 1018 & 3426 & 32543 & 74814 & 42271 & $2.2: 1$ \\
\hline $\mathbf{G}_{1} \mathbf{F}_{4}$ & 972 & 3287 & 32462 & 71483 & 39021 & $2.2: 1$ \\
\hline $\mathbf{G}_{1} \mathbf{F}_{5}$ & 676 & 2398 & 32151 & 50167 & 18016 & $1.5: 1$ \\
\hline $\mathbf{G}_{2} \mathbf{F}_{1}$ & 940 & 3119 & 30683 & 68878 & 38195 & $2.2: 1$ \\
\hline$\overline{G_{2} F_{2}}$ & 1185 & 4065 & 33834 & 87360 & 53526 & $2.5: 1$ \\
\hline $\mathbf{G}_{\mathbf{2}} \mathbf{F}_{\mathbf{3}}$ & 1176 & 4037 & 33753 & 86693 & 52940 & $2.5: 1$ \\
\hline $\mathbf{G}_{2} \mathbf{F}_{4}$ & 963 & 3370 & 33672 & 71261 & 37589 & $2.1: 1$ \\
\hline$\overline{\mathbf{G}_{2} \mathbf{F}_{5}}$ & 924 & 3357 & 33361 & 68868 & 35507 & $2.0: 1$ \\
\hline
\end{tabular}

Note: Selling price of Mungbean seed $=60(\mathrm{Rs} . / \mathrm{kg})$ and stover $=4.0(\mathrm{Rs} . / \mathrm{kg})$ 


\section{Interaction}

In the case of pods per plant, seeds per pod, seed and stover yields (Table 1) $\mathrm{G} \times \mathrm{F}$ interaction effect was found to be significant. Application of gypsum @ $2 \mathrm{t} \mathrm{ha}^{-1}$ and $100 \%$ $\mathrm{RDF}+$ Bio-compost $5 \mathrm{t} \mathrm{ha}^{-1}+$ bio fertilizer (Rhizobium + PSB) resulted into significantly higher seed yield (1185 $\left.\mathrm{kg} \mathrm{ha}^{-1}\right)$, stover yield (4065 kg ha-1), pods per plant (34.9), and seeds per pod (10.65). However, treatment $\mathrm{G}_{2} \mathrm{~F}_{3}$ remained at par with treatment $\mathrm{G}_{2} \mathrm{~F}_{2}$ in all the cases.

These results are in line with those published by Teotia et al., (2000) in mungbean, Ijgude and Kadam (2008) in soybean, Nawange et al., (2011) in chickpea and Nadan et al., (2012) in greengram.

\section{Economics}

As the interaction effect on seed and stover yields was significant, the economics was computed for combination. Among the different combinations, maximum net return of ₹ $53526 \mathrm{ha}^{-1}$ and BCR value of 2.5:1 were recorded under the treatment of $\mathrm{G}_{2} \mathrm{~F}_{2}$ (gypsum @ $2 \mathrm{t} \mathrm{ha}^{-1}$ and $100 \% \mathrm{RDF}+$ Bio-compost @ 5 $\mathrm{t} \mathrm{ha}{ }^{-1}+$ bio fertilizer (Rhizobium + PSB)) which was followed by $\mathrm{G}_{2} \mathrm{~F}_{3}$ (gypsum s@2 $\mathrm{t}$ ha $^{-1}$ and 75\% RDF + Bio-compost @ $5 \mathrm{t} \mathrm{ha}^{-1}+$ bio fertilizer (Rhizobium + PSB) with net return of ₹52940 ha ${ }^{-1}$ and identical BCR 2.5:1.

For obtaining higher seed yield of rabi mungbean under South Gujarat conditions, application of gypsum @ $2 \mathrm{t} \mathrm{ha}^{-1}$ alongwith $100 \%$ RDF+ Bio-compost @ 5 t ha ${ }^{-1}+$ bio fertilizer (Rhizobium +PSB) is necessary.

Similarly, application of $75 \%$ RDF $+5 \mathrm{t}$ $\mathrm{BC} / \mathrm{ha}+$ bio fertilizer (Rhizobium + PSB) was also found equally economical that too with saving of $25 \%$ fertilizer dose.

\section{References}

Bairwa, R. K., Nepalia, V., Balai, C. M., Chauhan, G. S. and Ram, B. 2012. Effect of phosphorus and sulphur on growth and yield of summer mungbean. Journal of Food Legumes, 25(3): 211214.

Gorade V. N., ChavanL. S., Jagtap D. N. and Kolekar A. B. 2014. Response of greengram (Vigna radiata L.) Varieties to integrated nutrient management in summer season. Agriculture Sciences Digest 34(1): 36 - 40.

Ijgude, M. B., and Kadam, J. R. 2008. Effect of phosphorus and sulphur on nutrient uptake in soybean. An Asian Journal of Soil Science, 3(11): 194-196.

Jat, R. L., and Rathore, P. S. 1994. Effect of sulphur, molybdenum and Rhizobium inoculation on greengram (Phaseolus radiatus L.). Indian Journal of Agronomy, 39(4):651-654.

Kundu, R., Mandal, J. and Majumder, A. 2013. Growth and Production Potential of Greengram (Vigna radiate L.)Influenced by Rhizobium Inoculation with Different Nutrient Sources. International Journal of Agriculture, Environment \& Biotechnology, 6(3):344-350.

Nawange, D.D., Yadav, A.S. and Singh, R.V. 2011. Effect of phosphorus and sulphur application on grwoth, yield attributes and yield of chickpea (Cicer arietinum L).Legume Research, 34(1): 48-50.

Nandan, Rajiv., Kaleem, Mohd. And Moinuddin. 2012. Rhizobium inoculation, phosphorus and sulphur fertilization and their effect on greengram (Vigna radiata). International Agronomy Congress.

Panse, V.G., and Sukhatme, P.V. 1967. Statistical Methods for Agricultural Workers. ICAR, New Delhi. pp. 187197. 
Patel, P.M., Patel, J.S., Patel, J.J., and Patel, H.K. 2010. Effect of levels and sources of sulphur on seed yield and quality of summer greengram. International Journal Agriculture Science, 6(1): 169171.

Patil, S. C., Jagtap, D. N. and Bhale, V. M. 2011. Effect of phosphorus and sulphur on growth and yield of moongbean. International Journal of Agricultural sciences, 7(2): 348-351.

Rajkhowa, D. J., Saikia, M. and Rajkhowa, K. M. 2002. Effect of vermicompost with and without fertilizer on greengram. Legume Research, 15(2): 131-135.

Singh, S. P., Ram Bhasose, A. and Suresh Kumar (2015).Response of summer mungbean to phosphorus and biofertilizers in eastern Uttar Pradesh.
Annals of Plant and Soil Research, 17(1): 104-105.

Teotia, U. S., Mehta, V. S., Ghosh, D. and Srivastava, P.C. 2000. Phosphorussulphur Interaction in moongbean on yield, phosphorus and sulphur contents. Legume Research, 23(1): 106-109.

Tyagi, P. K., and Upadhyay, A. K. 2015. Effect of integrated nutrient management on yield, quality, nutrients uptake and economics of summer greengram. Annals of Plant and Soil Research, 17(3): 242-247.

Vitnor, S., Lal, E. P. and Rao, K. P. 2015. Studies on Integrated Nutrient Management on Seed Yield and Quality of greengram (Vigna radiata L.).International Journal of Recent Research in Life Sciences, 2(2): 42-45.

\section{How to cite this article:}

Chaudhari, S.D., V.R. Naik, J.M. Patel and Sodavadiya, H.B. 2017. Effect of Soil Conditioner and INM on Yield of Mungbean (Co: 4) Grown on Partially Reclaimed Coastal Salt Affected Soil of South Gujarat, India. Int.J.Curr.Microbiol.App.Sci. 6(8): 2835-2840. doi: https://doi.org/10.20546/ijcmas.2017.608.338 